\title{
Spiral Chip Implantable Radiator and Printed Loop External Receptor for RF Telemetry in Bio-Sensor Systems
}

Rainee N. Simons

Glenn Research Center, Cleveland, Ohio

David G. Hall

ZIN Technologies, Inc., Brook Park, Ohio

Félix A. Miranda

Glenn Research Center, Cleveland, Ohio 
Since its founding, NASA has been dedicated to the advancement of aeronautics and space science. The NASA Scientific and Technical Information (STI) Program Office plays a key part in helping NASA maintain this important role.

The NASA STI Program Office is operated by Langley Research Center, the Lead Center for NASA's scientific and technical information. The NASA STI Program Office provides access to the NASA STI Database, the largest collection of aeronautical and space science STI in the world. The Program Office is also NASA's institutional mechanism for disseminating the results of its research and development activities. These results are published by NASA in the NASA STI Report Series, which includes the following report types:

- $\quad$ TECHNICAL PUBLICATION. Reports of completed research or a major significant phase of research that present the results of NASA programs and include extensive data or theoretical analysis. Includes compilations of significant scientific and technical data and information deemed to be of continuing reference value. NASA's counterpart of peerreviewed formal professional papers but has less stringent limitations on manuscript length and extent of graphic presentations.

- TECHNICAL MEMORANDUM. Scientific and technical findings that are preliminary or of specialized interest, e.g., quick release reports, working papers, and bibliographies that contain minimal annotation. Does not contain extensive analysis.

- CONTRACTOR REPORT. Scientific and technical findings by NASA-sponsored contractors and grantees.
- CONFERENCE PUBLICATION. Collected papers from scientific and technical conferences, symposia, seminars, or other meetings sponsored or cosponsored by NASA.

- SPECIAL PUBLICATION. Scientific, technical, or historical information from NASA programs, projects, and missions, often concerned with subjects having substantial public interest.

- TECHNICAL TRANSLATION. Englishlanguage translations of foreign scientific and technical material pertinent to NASA's mission.

Specialized services that complement the STI Program Office's diverse offerings include creating custom thesauri, building customized databases, organizing and publishing research results ... even providing videos.

For more information about the NASA STI Program Office, see the following:

- Access the NASA STI Program Home Page at http://www.sti.nasa.gov

- E-mail your question via the Internet to help@sti.nasa.gov

- Fax your question to the NASA Access Help Desk at 301-621-0134

- Telephone the NASA Access Help Desk at 301-621-0390

- Write to:

NASA Access Help Desk

NASA Center for AeroSpace Information 7121 Standard Drive

Hanover, MD 21076 
NASA/TM-2004-213217

\section{Spiral Chip Implantable Radiator and Printed Loop External Receptor for RF Telemetry in Bio-Sensor Systems}

Rainee N. Simons

Glenn Research Center, Cleveland, Ohio

David G. Hall

ZIN Technologies, Inc., Brook Park, Ohio

Félix A. Miranda

Glenn Research Center, Cleveland, Ohio

Prepared for the

Radio and Wireless Conference (RAWCON 2004)

sponsored by the Institute of Electrical and Electronics Engineers

Atlanta, Georgia, September 19-22, 2004

National Aeronautics and

Space Administration

Glenn Research Center 


\section{Acknowledgments}

The NASA Glenn Research Center's Commercial Technology Office under the research project entitled "RF Telemetry for BioMEMS Sensors and Actuators" supported this work. In addition, the authors are grateful to Dr. Jack East and Mr. Yongshik Lee, of the EECS Department, University of Michigan, Ann Arbor, for the fabrication of the spiral inductor with a serrated ground plane on a HR-Si wafer.

This report contains preliminary

findings, subject to revision as

analysis proceeds.

.

Available from

NASA Center for Aerospace Information 7121 Standard Drive

Hanover, MD 21076
National Technical Information Service 5285 Port Royal Road Springfield, VA 22100 


\title{
Spiral Chip Implantable Radiator and Printed Loop External Receptor for RF Telemetry in Bio-Sensor Systems
}

\author{
Rainee N. Simons, ${ }^{1}$ David G. Hall, ${ }^{2}$ and Félix A. Miranda ${ }^{1}$ \\ ${ }^{1}$ National Aeronautics and Space Administration, Glenn Research Center, Cleveland, Ohio 44135 \\ ${ }^{2}$ ZIN Technologies, Inc., Brook Park, Ohio 44142
}

\begin{abstract}
The paper describes the operation of a patented wireless RF telemetry system, consisting of a bio-MEMS implantable sensor and an external hand held unit, operating over the frequency range of few hundreds of MHz. A MEMS capacitive pressure sensor integrated with a miniature inductor/antenna together constitute the implantable sensor. Signal processing circuits collocated with a printed loop antenna together form the hand held unit, capable of inductively powering and also receiving the telemetry signals from the sensor. The paper in addition, demonstrates a technique to enhance the quality factor and inductance of the inductor in the presence of a lower ground plane and also presents the radiation characteristics of the loop antenna.
\end{abstract}

\section{INTRODUCTION}

The biological and physical sciences program at NASA seeks to develop telemetry based implantable sensing systems to monitor the physiological parameters of humans during space flights [1]. This focus is rather unique when compared to efforts by other investigators, which have been mainly in the area of $\mathrm{RF} /$ microwave applications in medical treatment and biological effects [2]. In two recent papers [3], [4], the authors have presented the development of a micro inductor/antenna for implantable bio-microelectromechanical systems (bio-MEMS) based capacitive pressure sensors and a printed multi-turn loop antenna for an external hand held unit, respectively. In the above developmental effort, the loop antenna through the inductor/antenna activates and also acquires RF telemetry data from the implanted sensor. In addition to the above, a third paper by the authors demonstrated signal coupling through stratified media represented by muscle tissue-like and fatty tissue-like phantoms placed between the micro inductor/antenna and the loop antenna [5].

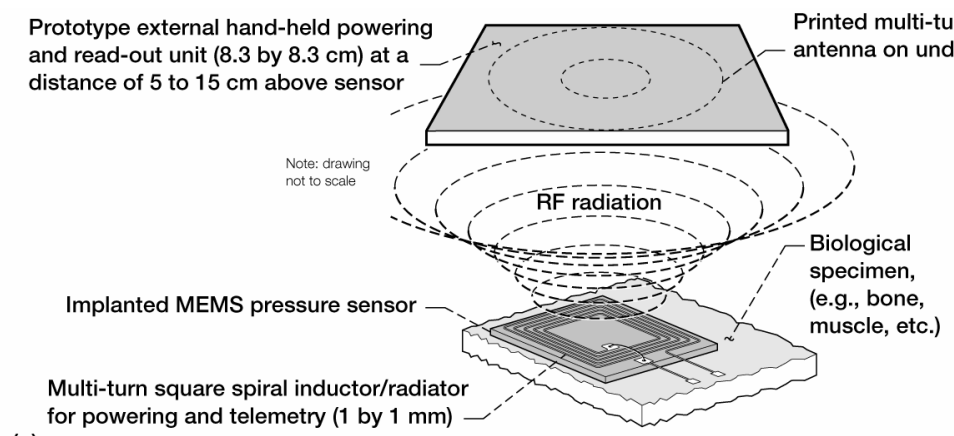

(a)

for powering and telemetry ( 1 by $1 \mathrm{~mm})$

Fig. 1. Contact-less powering and telemetry. (a) Concept. (b) Application in biosensors.
In this paper, we further advance the development of the implantable inductor/antenna by taking into consideration the presence of an inevitable lower ground plane and its influence on the inductance and quality factor. In addition, we also investigate the radiation patterns of the printed multi-turn loop antenna in the external hand held unit. The above investigations are covered by two patent applications, one of which has been recently granted [6], [7].

\section{WIRELESS RF TELEMETRY SYSTEM}

The contact-less powering and telemetry concept, including the miniature square spiral inductor/antenna circuit intended for integration with a MEMS pressure sensor, is illustrated in Fig. 1(a). The pressure sensor is of the capacitive type and is located in the annular region of the inductor. The inductor behaves both as an inductance as well as an antenna thereby allowing the sensor to receive as well as radiate out energy. In the receive mode, the inductance picks up energy and charges the MEMS pressure sensor diaphragm capacitance. In the transmit mode, the above inductance and capacitance form a parallel resonant circuit and radiate energy through the inductor which now behaves as a planar spiral antenna. To obtain a pressure reading, a pulse emitted by the hand held unit initially interrogates the sensor. At the rising and the falling edges of this pulse a voltage is induced in the spiral inductor thus implementing contact less powering. The waveform of this induced voltage is a decaying sine wave. These oscillations also cause the inductor to radiate energy that is picked up as a telemetry signal by the receiving antenna in the hand held unit. Since the inductance of the implanted sensor circuit is fixed, the frequency of the decaying sine wave is mainly determined by the capacitance introduced by the sensor. Thus, the larger the pressure difference, the larger the frequency offset between the received telemetry in the two pressure states. The implanted bio-MEMS sensor and the hand held unit together form the wireless RF telemetry system [6], [7] as illustrated in Fig. 1(b). 


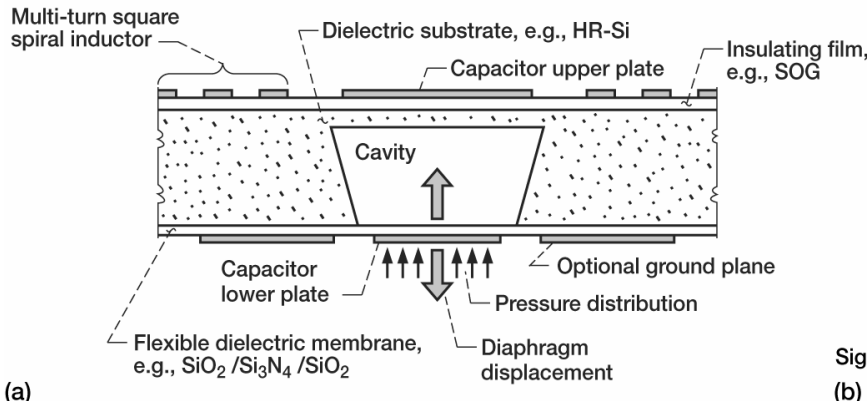

(a)

Fig. 2. (a) Schematic of a capacitive pressure sensor. (b) Schematic of a miniature spiral inductor/antenna on SOG/HR-Si wafer (c) Photomicrograph of inductor/antenna.

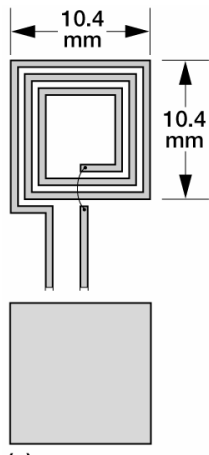

(a)

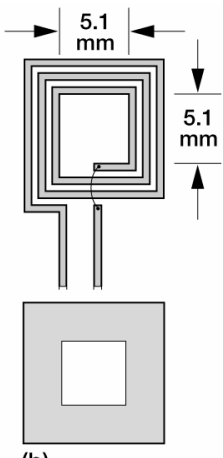

(b)

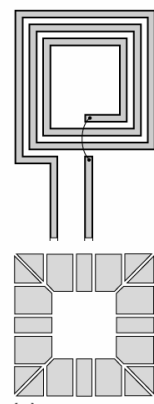

(c)
Fig. 3. Top and bottom view of square spiral inductor with various ground patterns. Substrate is Duroid®. The strip conductor and gap widths are $0.635 \mathrm{~mm}$ and $0.381 \mathrm{~mm}$, respectively. (a) Solid full ground plane. (b) Solid ring ground plane. (c) Serrated ring ground plane. (d) No ground plane.

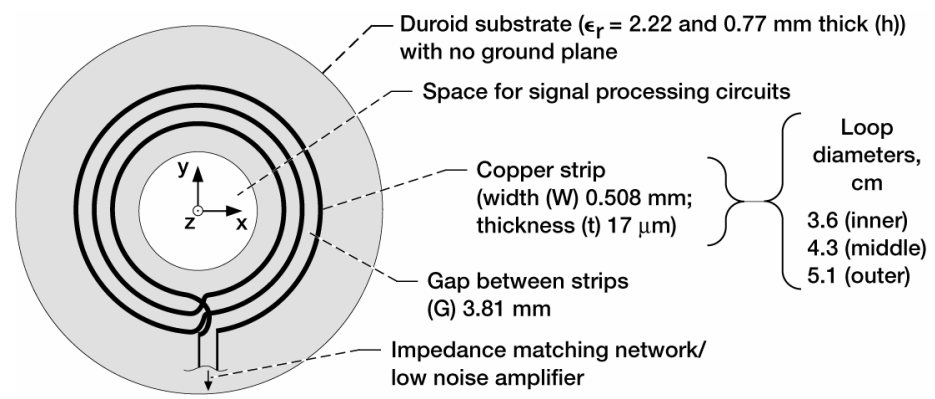

Fig. 4. Printed multi-turn loop antenna on a dielectric ring.

\section{Pressure Sensor and SQuare Spiral ChIP INDUCTOR/ANTENNA}

A schematic rendition of the pressure sensor is shown in Fig. 2(a). The pressure sensor consists of a diaphragm suspended over a cavity micromachined from a silicon wafer and is of the capacitive type with capacitance change in the range of 0.3 to $4 \mathrm{pF}$ [3].

Figure 2(b) shows a schematic of the square spiral chip inductor/antenna. The outer dimensions of the inductor are

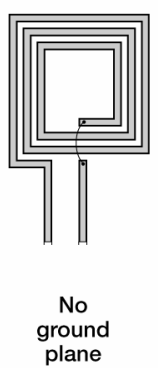

(d) about $1 \times 1 \mathrm{~mm}$, and the inductor is fabricated on a spin-on-glass (SOG) coated high resistivity silicon (HR-Si) wafer to reduce the attenuation of the signals. An initial estimate based on the capacitance values of the pressure sensor show that an inductance (L) with a quality factor (Q) of about $150 \mathrm{nH}$ and 10 respectively, are adequate for the application described above. The frequency range over which this device is intended to operate is from 200 to $700 \mathrm{MHz}$ which includes the Federal Communications Commission (FCC) designated bands. Figure 2(c) shows a SEM picture of a typical inductor/antenna circuit. The fabrication procedures as well as the results of a parametric study of these inductors are presented in [3].

The presence of a parasitic lower ground plane introduced by the capacitive pressure sensor degrades the inductance and quality factor of the inductor. Hence, to investigate these problems spiral inductors with different types of ground planes as illustrated in Fig. 3 were fabricated. In the initial phase of the study, the inductors were expeditiously fabricated on low cost copper-clad Duroid ${ }^{\circledR}$ (registered trademark of Rogers Corporation) substrates and evaluated. From this study, the most promising design was picked and transferred to silicon, which is the material of choice for the sensor. Subsequently, several inductors based on this design concept were fabricated on a HR-Si wafer.

\section{Printed Multi-Turn LoOP ANTENNA}

The printed multi-turn loop antenna in the hand held unit is illustrated in Fig. 4. For maximum sensitivity, the input impedance of the loop antenna is matched by a lumped element PI-network to the $50 \Omega$ input impedance of the MMIC low noise amplifier (LNA) chip in the receiver. The circuit and fabrication details of the antenna are presented in [3]. 


\section{EXPERIMENTAL RESULTS AND DISCUSSIONS}

\section{A. Inductance of Square Spiral Inductor with Different Types of Ground Planes on Duroid $\AA$}

The circuits are experimentally characterized by measuring the return loss $S_{11}$ using on-wafer RF probing techniques. From the measured $S_{11}$, the inductance $\mathrm{L}$ and the quality factor $\mathrm{Q}$ are analytically determined. Figure 5 shows the inductances as a function of the frequency for inductors with four types of ground planes. It is observed that the inductance degrades in the presence of either a solid full or a solid ring ground plane. This is because the image current in the aforementioned ground planes flows in a direction opposite to the current on the spiral thereby reducing the magnetic field and thus the overall inductance [8], [9]. In contrast, it is interesting to observe that the inductance of the inductor with a serrated ring ground plane is about the same as that of an inductor without a ground plane. This is because the slots in serrated ground plane act as open circuits and thus suppress the flow of image current [8], [9].

\section{B. Quality Factor of Square Spiral Inductor with Different Types of Ground Planes on Duroid $\circledR$}

The peak $\mathrm{Q}$ value for the four inductors shown in Fig. 3 are presented in Table I. It is interesting to note that the peak Q for the inductors with and without a serrated ground plane is about the same. From this initial study of L and Q it was concluded that the serrated ground plane is ideally suited for mitigating image current effects.

C. Inductance and Quality Factor of Square Spiral Inductor with Serrated Ground Plane on High Resistivity Silicon Wafer

The $\mathrm{L}$ and $\mathrm{Q}$ of the inductors in previously reported studies [3] were without a lower ground plane. From that study it was

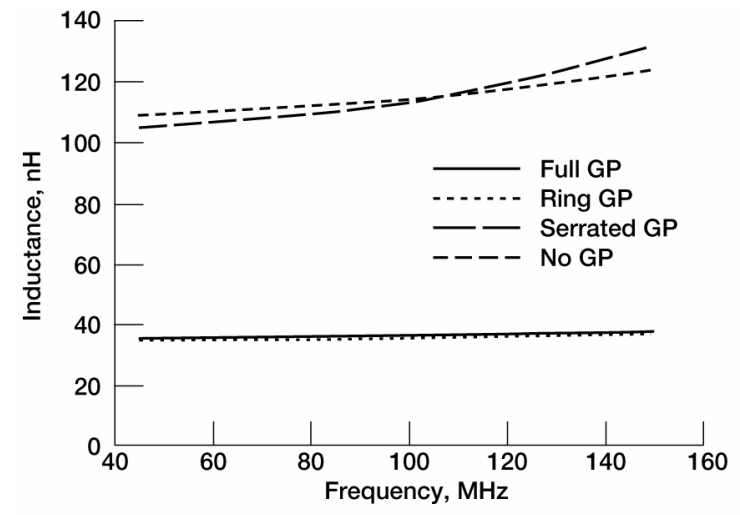

Fig. 5. Measured inductance of square spiral inductors with different types of ground planes (GP) on Duroid $®$ substrates.

TABLE I

SPIRAL INDUCTOR QUALITY FACTOR WITH DIFFERENT TYPES OF GROUND PLANES

\begin{tabular}{|c|c|}
\hline Ground Plane Type & Quality factor \\
\hline Solid Full Ground Plane & 40.6 \\
\hline Solid Ring Ground Plane & 37.3 \\
\hline Serrated Ring Ground Plane & 73.0 \\
\hline No Ground Plane & 78.3 \\
\hline
\end{tabular}

Material: Duroid®, Substrate Dielectric Constant: 10.5

Substrate Thickness: $0.254 \mathrm{~mm}$, Conductor: Copper

Conductor Thickness: $17 \mu \mathrm{m}$, Frequency: $230 \mathrm{MHz}$ evident that peak $\mathrm{Q}$ and corresponding $\mathrm{L}$ as high as 10.5 and $153 \mathrm{nH}$ respectively were achievable. To investigate the effect of the lower ground plane, this inductor was reproduced on a HR-Si wafer with a serrated ground plane on the opposite side. The measured $\mathrm{Q}$ and $\mathrm{L}$ as a function of frequency are presented in Fig. 6. The peak $Q$ and the corresponding $L$ are about 8.2 and $130 \mathrm{nH}$, respectively. By comparing the two sets of results it is evident that there is a small degradation in the peak $Q$ and corresponding L values. Nevertheless, the serrated ground plane clearly demonstrates its efficacy to mitigate image currents effects.

\section{Radiation Pattern of Printed Multi-Turn Loop Antenna}

In Fig. 7, the experimental setup for measuring the radiation patterns of the multi-turn loop antenna in the hand held unit and the coordinate system are schematically illustrated. A short dipole antenna is used as the transmitting antenna. In a typical medical diagnostic situation, the radiation emanating from the implanted chip radiator may be vertically, horizontally or slant polarized. Hence, to emulate all possibilities, the radiation

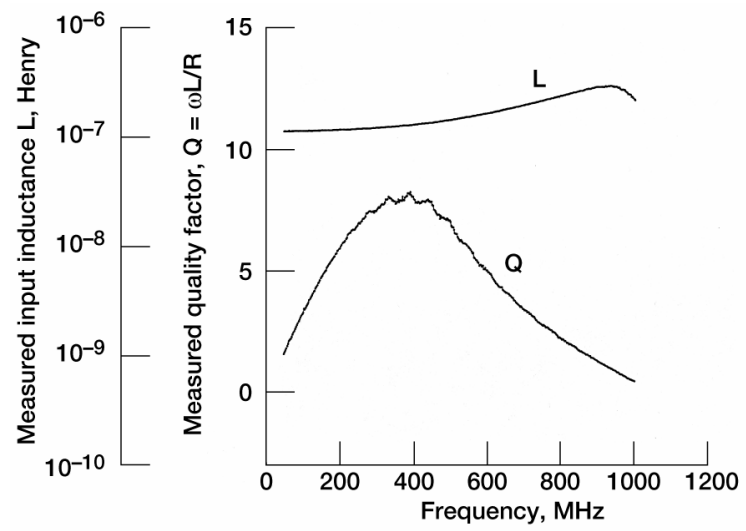

Fig. 6. Measured inductance and quality factor for an inductor with a serrated ring ground plane on a HR-Si wafer. No SOG layer. The thickness of the gold conductor on the top and bottom are about $1.5 \mu \mathrm{m}$ and $1.8 \mu \mathrm{m}$, respectively. The wafer thickness is about $400 \mu \mathrm{m}$.

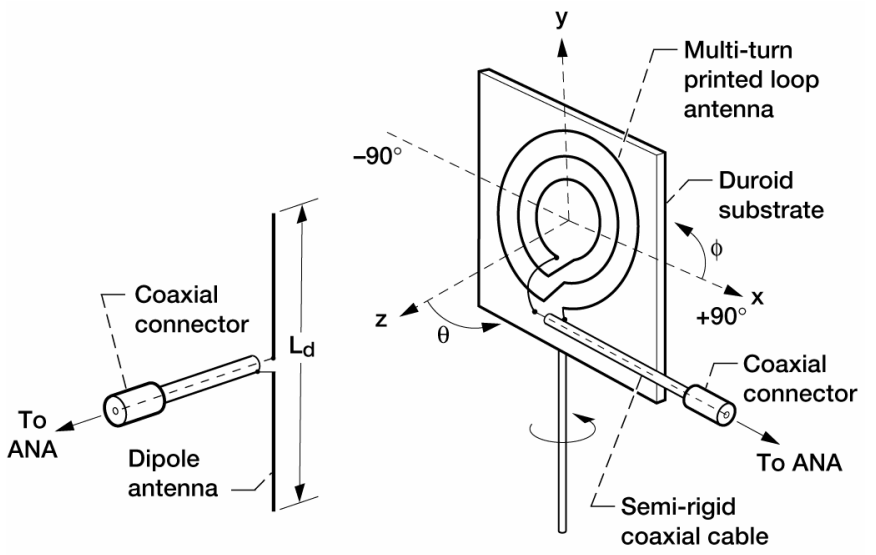

Fig. 7. Schematic illustrating the experimental setup for measuring the loop antenna radiation patterns using an automatic network analyzer (ANA) and the coordinate system. The dipole length $\mathrm{L}_{\mathrm{d}}$ is about $0.1 \lambda_{0}$, where $\lambda_{0}$ is the free space wavelength at the measurement frequency. 


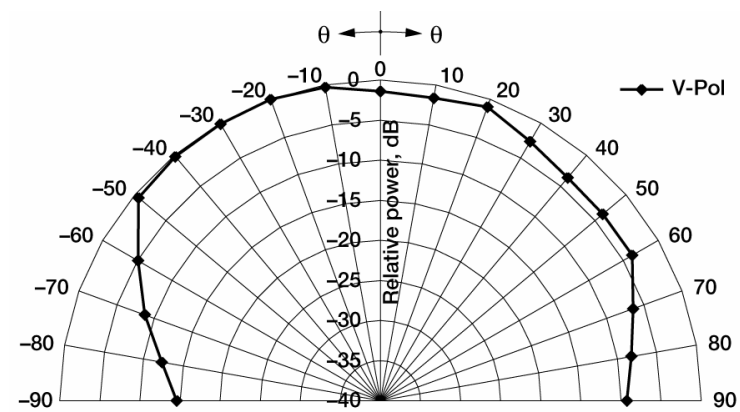

(a)

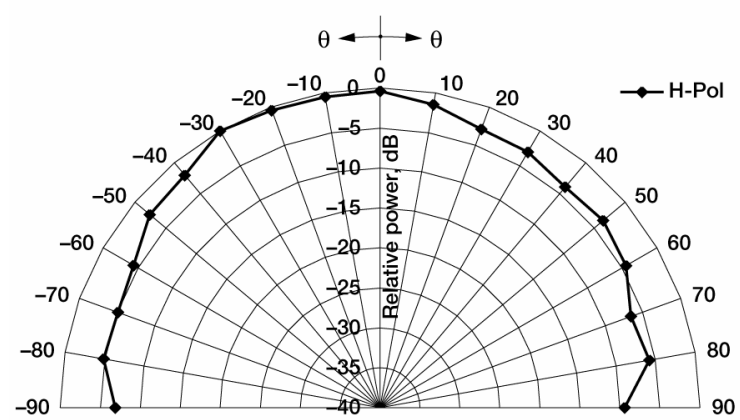

(b)

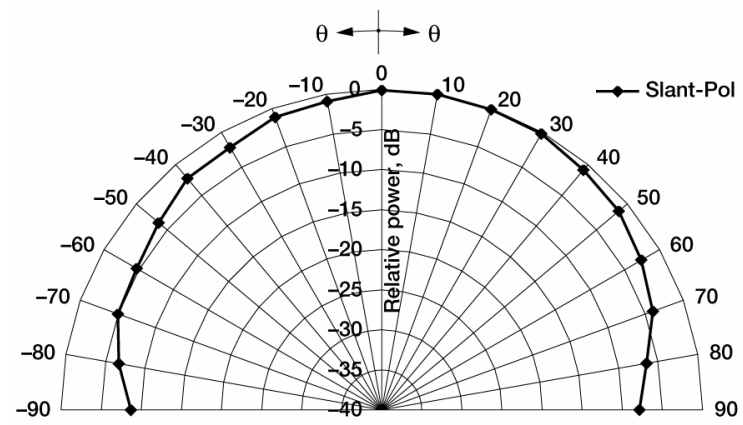

(c)

Fig. 8. Measured radiation patterns of the loop antenna at $330 \mathrm{MHz}$ in the $\phi=0^{\circ}$ or $\mathrm{x}-\mathrm{z}$ plane when the incident wave is: (a) Vertically polarized (y-axis). (b) Horizontally polarized (x-axis). (c) Slant polarized $\left(45^{\circ}\right)$.

pattern of the loop is measured with the transmitting dipole vertically, horizontally, and slant $\left(45^{\circ}\right)$ polarized. In Fig. 8, the measured radiation patterns of the multi-turn loop in the $\phi=0^{\circ}$ or horizontal $(\mathrm{x}-\mathrm{z})$ plane are presented. Since the loop antenna is symmetric it is expected to have similar patterns in the $\phi=$ $90^{\circ}$ or vertical $(\mathrm{y}-\mathrm{z})$ plane also. From these measurements it is inferred that the loop is a very versatile antenna capable of providing hemispherical coverage and also receiving signals with any of the above polarizations.

\section{E. Received Relative Signal Strength}

To emulate a typical operating condition in a medical diagnostic application, the hand held unit with the loop antenna is held at a height of $10 \mathrm{~cm}$ and coaxial with the inductor. The measured relative signal strength magnitudes are presented in [3] and [5]. It is observed that at the frequency of best impedance match, the loop is capable of discriminating against noise with better than $20 \mathrm{~dB}$ signal-to-noise ratio.

\section{ConCLUSIONS}

The development of a wireless RF telemetry system, consisting of a bio-MEMS implantable sensor and an external hand held unit, operating over the frequency range of few hundreds of $\mathrm{MHz}$ is presented. In addition, the use of a serrated ground plane instead of a continuous ground plane to mitigate detrimental effects of image currents on inductance and quality factor of printed inductors is demonstrated. Furthermore, radiation pattern measurements demonstrate that the multi-turn loop antenna in the hand held unit is capable of providing hemispherical coverage and also receiving signals emanating from the implanted sensor with vertical, horizontal or slant polarization.

\section{REFERENCES}

[1] J.W. Hines, "Medical and Surgical Applications of Space Biosensor Technology," Acta Astronautica, Vol. 38, Nos. 4-8, pp. 261-267, Feb.-April 1996.

[2] Mini-Special Issue on RF/Microwave Applications in Medicine (Part I) and Special Issue on Medical Application and Biological Effects of RF/Microwaves (Part II), IEEE Trans. Microwave Theory Tech., Vol. 48, No. 11, Nov. 2000.

[3] R.N. Simons, D.G. Hall, and F.A. Miranda, "RF Telemetry System for an Implantable Bio-MEMS Sensor," IEEE MTT-S Inter. Microwave Symp. Digest, Vol. 3, pp. 1433-1436, Fort Worth, TX, June 6-11, 2004.

[4] R.N. Simons, D.G. Hall, and F.A. Miranda, "Printed Multi-Turn Loop Antenna for RF Bio-Telemetry," IEEE Antennas and Propagation Society Inter. Symp. Digest, Vol. 2, pp. 1339-1342, Monterey, CA, June 20-25, 2004.

[5] F.A. Miranda, R.N. Simons, and D.G. Hall, "Validation of Radio Frequency Telemetry Concept in the Presence of Biological Tissue-Like Stratified Media," IEEE Antennas and Propagation Society Inter. Symp. Digest, Vol. 2, pp. 1335-1338, Monterey, CA, June 20-25, 2004.

[6] R.N. Simons and F.A. Miranda, Radio Frequency Telemetry System for Sensors and Actuators, U.S. Patent No. 6667725, Dec. 23, 2003.

[7] F.A. Miranda and R.N. Simons, Hand Held Device for Wireless Powering and Interrogation of Bio-MEMS Sensors and Actuators, LEW 17, 483-1, July 2003.

[8] C.P. Yue and S.S. Wong, "On-Chip Spiral Inductors with Patterned Ground Shields for Si-Based RF IC's" IEEE Jour. Solid-State Circuits, Vol. 33, No. 5, pp. 743-752, May 1998.

[9] C.A. Chang, S.-P. Tseng, J.Y. Chuang, S.-S. Jiang, and J.A. Yeh, "Characterization of Spiral Inductors With Patterned Floating Structures," IEEE Trans. Microwave Theory Tech., Vol. 52, No. 5, pp. 1375-1381, May 2004. 

Public reporting burden for this collection of information is estimated to average 1 hour per response, including the time for reviewing instructions, searching existing data sources, gathering and maintaining the data needed, and completing and reviewing the collection of information. Send comments regarding this burden estimate or any other aspect of this collection of information, including suggestions for reducing this burden, to Washington Headquarters Services, Directorate for Information Operations and Reports, 1215 Jefferson Davis Highway, Suite 1204, Arlington, VA 22202-4302, and to the Office of Management and Budget, Paperwork Reduction Project (0704-0188), Washington, DC 20503.

\begin{tabular}{|l|l|l}
\hline 1. AGENCY USE ONLY (Leave blank) & $\begin{array}{c}\text { 2. REPORT DATE } \\
\text { August } 2004\end{array}$ & $\begin{array}{c}\text { 3. REPORT TYPE AND DATES COVERED } \\
\text { Technical Memorandum }\end{array}$
\end{tabular}

4. TITLE AND SUBTITLE

5. FUNDING NUMBERS

Spiral Chip Implantable Radiator and Printed Loop External Receptor for RF

Telemetry in Bio-Sensor Systems

6. AUTHOR(S)

Rainee N. Simons, David G. Hall, and Félix A. Miranda

WBS-22-251-30-15

7. PERFORMING ORGANIZATION NAME(S) AND ADDRESS(ES)

National Aeronautics and Space Administration

John H. Glenn Research Center at Lewis Field

Cleveland, Ohio 44135-3191

8. PERFORMING ORGANIZATION

REPORT NUMBER

E-14501

9. SPONSORING/MONITORING AGENCY NAME(S) AND ADDRESS(ES)

National Aeronautics and Space Administration

Washington, DC 20546-0001

10. SPONSORING/MONITORING

AGENCY REPORT NUMBER

NASA TM-2004-213217

T3A-5

\section{SUPPLEMENTARY NOTES}

Prepared for the Radio and Wireless Conference (RAWCON 2004) sponsored by the Institute of Electrical and Electronics Engineers, Atlanta, Georgia, September 19-22, 2004. Rainee N. Simons and Félix A. Miranda, NASA Glenn Research Center; and David G. Hall, ZIN Technologies, Inc., 3000 Aerospace Parkway, Brook Park, Ohio 44142. Responsible person, Rainee N. Simons, organization code 5620, 216-433-3462.

12a. DISTRIBUTION/AVAILABILITY STATEMENT

12b. DISTRIBUTION CODE

Unclassified - Unlimited

Subject Category: 33

Distribution: Nonstandard

Available electronically at http://gltrs.grc.nasa.gov

This publication is available from the NASA Center for AeroSpace Information, 301-621-0390.

13. ABSTRACT (Maximum 200 words)

The paper describes the operation of a patented wireless RF telemetry system, consisting of a bio-MEMS implantable sensor and an external hand held unit, operating over the frequency range of few hundreds of MHz. A MEMS capacitive pressure sensor integrated with a miniature inductor/antenna together constitute the implantable sensor. Signal processing circuits collocated with a printed loop antenna together form the hand held unit, capable of inductively powering and also receiving the telemetry signals from the sensor. The paper in addition, demonstrates a technique to enhance the quality factor and inductance of the inductor in the presence of a lower ground plane and also presents the radiation characteristics of the loop antenna.

\begin{tabular}{|c|c|c|}
\hline $\begin{array}{l}\text { 14. SUBJECT TERMS } \\
\text { Spiral inductors; Bio-ME } \\
\text { pressure sensor; Wireles }\end{array}$ & $\begin{array}{l}\text { MS; Bio-sensor system; Biomed } \\
\text { ensing; Loop antenna }\end{array}$ & al RF telemetry; Capacitive \\
\hline $\begin{array}{l}\text { 17. SECURITY CLASSIFICATION } \\
\text { OF REPORT } \\
\text { Unclassified }\end{array}$ & $\begin{array}{l}\text { 18. SECURITY CLASSIFICATION } \\
\text { OF THIS PAGE } \\
\text { Unclassified }\end{array}$ & $\begin{array}{l}\text { 19. SECURITY CLASSIFICATION } \\
\text { OF ABSTRACT } \\
\text { Unclassified }\end{array}$ \\
\hline
\end{tabular}

15. NUMBER OF PAGES

10

16. PRICE CODE

20. LIMITATION OF ABSTRACT

Standard Form 298 (Rev. 2-89)

Prescribed by ANSI Std. Z39-18 298-102 

